\title{
Evaluation of immune responses of cattle as a means to identify high or low responders and use of a human microarray to differentiate gene expression
}

\author{
Armando HERnÁNDEZ ${ }^{\mathrm{a}}$, Niel KARROw ${ }^{\mathrm{b}}$, \\ Bonnie A. MALlARD ${ }^{\text {a* }}$ \\ a Ontario Veterinary College, Department of Pathobiology, \\ University of Guelph, Guelph, Ontario, Canada \\ ${ }^{b}$ Animal and Poultry Science, Center for Genetic Improvement of Livestock, \\ University of Guelph, Guelph, Ontario, Canada
}

(Accepted 26 February 2003)

\begin{abstract}
An immune response (IR) index to identify cows with high (H) and low (L) antibodymediated immune responses (AMIR) had been previously devised. High AMIR associated with decreased mastitis and improved response to vaccination. Measurement of cell-mediated immune response (CMIR) was not included in the index; therefore various antigen/adjuvant combinations were evaluated as inducers of DTH to be added to the IR-index. The Bacillus Calmette Guérin (BCG)-induced/purified protein derivative (PPD)-elicited tuberculin skin test is a reliable measure of DTH; however, its use to identify livestock with high CMIR may be confounded due to previous exposure to Mycobacteria tuberculosis. DTH to BCG/PPD was therefore compared with that induced by Mycobacteria phlei (saprophyte) and its derivative phlein as the test antigen. Antibody to OVA was also evaluated. The results indicated that BCG/PPD and M. phlei/phlein induced similar DTH, but cross reaction to PPD was evident following induction of DTH using $M$. phlei making it a less than ideal alternative for testing livestock. Nonetheless, cows could be ranked for both AMIR and CMIR. RNA from two cows with the highest and lowest IR ranks was then used to probe a human $1.7 \mathrm{kD}$ microarray to determine the ability of a human array to provide information on bovine genes associated with $\mathrm{H}$ and $\mathrm{L}$.
\end{abstract}

dairy cows / antibody response / delayed-type hypersensitivity / selection / microarray

\section{INTRODUCTION}

Improving both antibody (AMIR) and cell-mediated immune responses (CMIR) may enhance resistance to infectious diseases of livestock. Studies of

\footnotetext{
* Correspondence and reprints

E-mail: Bmallard@ovc.uoguelph.ca
} 
Yorkshire pigs selected for eight generations for high (H) and low (L) immune responses based on combined estimated breeding values (EBV) of both AMIR and CMIR demonstrated health and production benefits using a selection index approach [10,23]. More recently, a mathematical index to identify periparturient cows with $\mathrm{H}, \mathrm{L}$, and average (A) serum AMIR has been devised and high AMIR associated with an increased response to vaccination and with decreased mastitis in two out of three herds surveyed [18]. However, an indicator of CMIR was not included in this index. An indicator of CMIR, such as delayed-type hypersensitivity (DTH), could likely be used to classify cattle as was previously reported for pigs $[10,23]$. The combination of both AMIR and DTH may be useful to classify and select cattle for broad-based disease resistance [11]. It is therefore relevant to find antigen-adjuvant combinations that elicit both AMIR and CMIR, with the heritable characteristics required to make genetic selection feasible. The objective of this study was to find antigen-adjuvant combinations used in a simple, safe and effective immunization protocol that induce both AMIR and CMIR, and will allow cows to be categorized as H, L or A based on these responses. Categorization of cows based on AMIR and CMIR is a first step towards the selection of cattle for broad-based disease resistance. The possibility of using a human microarray to fingerprint bovine genes associated with $\mathrm{H}$ and $\mathrm{L}$ phenotypes was also investigated.

\section{MATERIALS AND METHODS}

\subsection{Immunization protocols}

Six groups of five non-lactating (dry) Holstein cows from 16 sires and different dams were randomly assigned to one of the following treatment groups (refer to Fig. 1 for an overview of treatments and immunization schedule): on day 0 , treatment group I (TG-I) received $1 \mathrm{mg}$ of OVA (chicken albumin grade VII) dissolved in $0.3 \mathrm{~mL}$ of phosphate buffered saline (PBS, $\mathrm{pH} 7.4$ ) and emulsified with $0.7 \mathrm{~mL}$ of non-ulcerative Freund adjuvant (NUFA; Cedarlane Laboratories Ltd., Hornby, Ont., Canada). This group was considered the DTH negative control since cows did not receive mycobacteria or any of its components for induction of CMIR. Treatment group II (TG-II) received OVA in PBS emulsified with $0.5 \mathrm{~mL}$ of FCA $(0.5 \mathrm{mg}$ heat-killed M. tuberculosis H37Ra emulsified in water-in-mineral oil adjuvant, Sigma-Aldrich Canada Ltd.) and $0.1 \mathrm{~mL} \mathrm{BCG} \mathrm{(0.1} \mathrm{mg} \mathrm{attenuated} \mathrm{live} M$. bovis). This was considered the DTH-positive control, since cows received both heat-killed $M$. tuberculosis as a component of FCA and live M. bovis BCG. Treatment group III (TG-III) received OVA in PBS emulsified with complete NUFA (CNUFA; $0.5 \mathrm{mg}$ killed Mycobacterium tuberculosis H37 RA, DIFCO Laboratories, Detroit, MI., USA; emulsified in NUFA). Treatment group IV (TG-IV) received OVA 


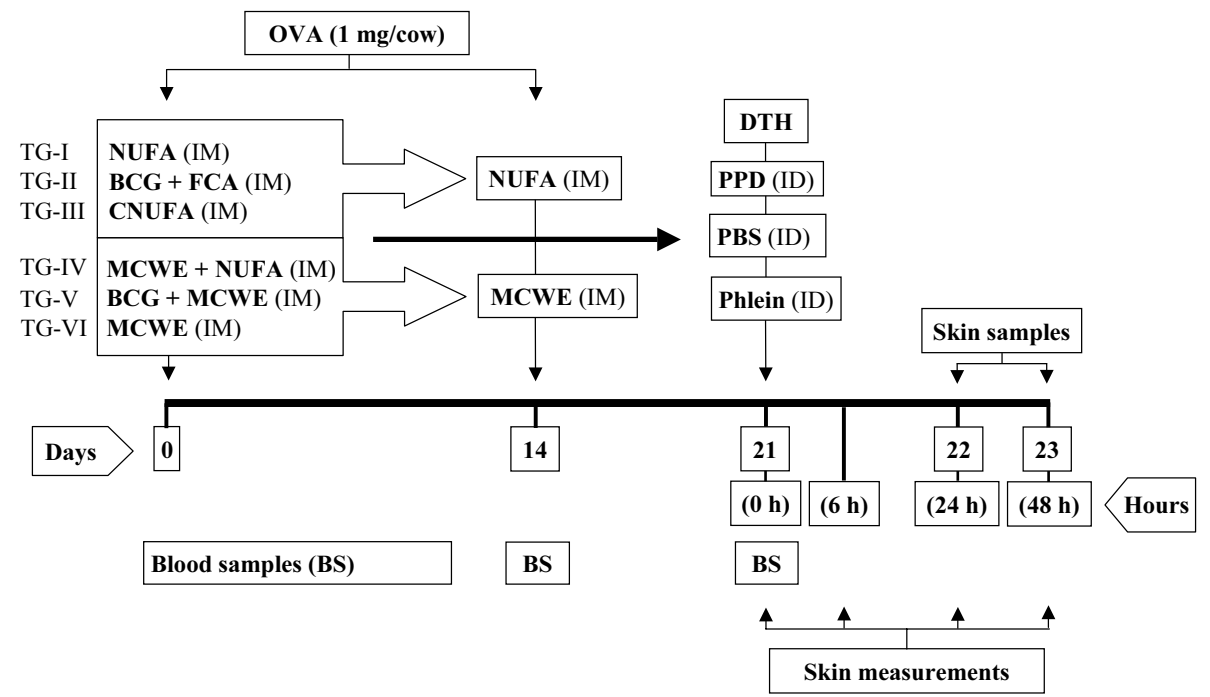

Figure 1. The imunization schedule used to induce antibody to ovalbumin (OVA) and delayed-type hypersensitivity (DTH) to mycobacteria.

in PBS together with $0.6 \mathrm{mg}$ of Mycobacterium phlei cell wall extract (MCWE suspended in $0.4 \mathrm{~mL}$ of PBS, Vetrepharm, Inc., London, Ont., Canada) suspended in $0.7 \mathrm{~mL}$ NUFA. Treatment group V (TG-V) received OVA in PBS together with $0.6 \mathrm{mg}$ of MCWE, and $0.1 \mathrm{~mL}$ BCG. Treatment group VI (TG-VI) received OVA in PBS together with $0.6 \mathrm{mg}$ of MCWE. All injections were given intramuscularly (IM), except for BCG, which was injected intradermally (ID). Different volumes of diluents and adjuvants were used to accommodate delivery of equal mounts of antigen and to provide the manufacturer's recommended proportion of antigen-adjuvant in each treatment combination.

On day 14, TG-I, II and III were given $1 \mathrm{mg}$ of OVA in PBS emulsified with NUFA $(0.7 \mathrm{~mL})$, and TG-IV, V and VI received $1 \mathrm{mg}$ of OVA in PBS together with $0.6 \mathrm{mg}$ of MCWE IM, in accordance with the homologous mycobacteria species given on day 0 .

\subsection{Antibodies to ovalbumin (OVA)}

Blood samples for determining serum antibody to OVA were taken on days 0,14 and 21. Antibodies to OVA were measured by enzyme-linked immunosorbent assay (ELISA) as previously described [21].

\subsection{Double skin-fold thickness as an indicator of DTH}

On day 21, all cows were tested in accordance with the sensitization antigen received on day 0 with either $0.1 \mathrm{~mL}$ M. bovis PPD (250 US tuberculin units, 
Canadian Food Inspection Agency, Nepean, Ont.) or $0.1 \mathrm{mg}$ of $M$. phlei PPD (phlein, kindly provided by Dr. Bob Duncan, Canadian Food Inspection Agency) ID in the right and left side of the neck. TG-I, II and III were tested with PPD, whereas TG-IV, V and VI were tested with phlein. The negative control (TG-I) was tested with PPD since this is the regulatory antigen for the tuberculin (Tb) test. Double skin-fold thickness measurements (three repetitions) of each site were taken with a spring-loaded caliper (Harpenden skin-fold caliper, Ann Arbor, MI, USA) before the injections on day $21(\mathrm{~h}=0)$ and 6,24 and $48 \mathrm{~h}$ after the injections. Delayed-type hypersensitivity was confirmed by microscopic evaluation (data not shown).

\subsection{Variation in antibodies to OVA and DTH to mycobacteria}

The cows of each treatment group were classified as high, low or average immune responders based on their antibody to OVA on days 14 and 21 and DTH response to mycobacteria at 24 and $48 \mathrm{~h}$ using the mean and standard deviation of each group and response. Specifically, the OD of serum antibody was used to classify cows for AMIR and the double skin-fold thickness percent increase to PPD or phlein was used to classify cows for DTH. Those cows that were above or below 1 standard deviation of the treatment group mean were classified as $\mathrm{H}$ and $\mathrm{L}$, respectively. Cows between both standard deviations were classified as average (A). Lymphocyte proliferation assays using $5 \mu \mathrm{g} \cdot \mathrm{mL}^{-1}$ concanavalin-A (Con-A) and $80 \mu \mathrm{g} \cdot \mathrm{mL}^{-1}$ OVA were performed [9] to confirm the $\mathrm{H}$ or L phenotype immediately prior to microarray gene expression profiling.

\subsection{Microarray gene expression profiling}

Blood lymphocytes from two cows, one with the highest (cow 22) and one with the lowest (cow 8) IR phenotypes (determined based on mean AMIR and DTH responses $+/-$ the standard deviation as described in section 2.4), and having significant differences $(P \leq 0.05)$ in lymphocyte blastogenesis to Con-A and OVA immediately prior to collection of RNA were cultured in complete IMDM $\left(2.5 \times 10^{6}\right.$ cells $\left.\cdot \mathrm{mL}^{-1}\right)$ overnight at $37^{\circ} \mathrm{C}$ and $5 \% \mathrm{CO}_{2}$. Total RNA was extracted for each experimental condition using the GenElute Miniprep kit (Sigma-Aldrich Canada Ltd.). RNA from the H and L cows was reverse transcribed, indirectly labeled with Cy5 (Red) or Cy3 (Green) respectively, and hybridized to a $1.7 \mathrm{~K}$ human microarray according to the manufacturer's protocol [12]. Hybridized arrays were scanned on a GenePix 4000 Scanner (Axon Instruments Inc., Union City, CA, USA) and the images were analyzed and tabulated using GenePix Pro 3.0 software. Following array normalization and background subtraction using GenPix Pro 3.0, genes with $\mathrm{Cy} 5 / \mathrm{Cy} 3$ ratio intensities of greater than 2.0 or less than 0.5 in the OVA and 
Con-A activated cultures were compared to the non-activated cultures (cells in the medium alone).

\subsection{Statistical analyses}

The SAS ${ }^{\circledR}$ statistical package [17] was used for most statistical analyses and graphic presentation of the data. The minimum level of significance is reported as $P \leq 0.05$. The statistical analyses of AMIR, and DTH were performed using a general linear mixed model (PROC Mixed, SAS ${ }^{\circledR}$ ), and estimated least squares means (LSM) were used in multiple comparisons. The AMIR and DTH measurements were log transformed to normalize and analyze the data. The model for AMIR was as follows:

$$
\mathrm{y}_{\mathrm{ijk}}=\mathrm{c}_{\mathrm{ik}}+\mathrm{t}_{\mathrm{j}}+\mathrm{f}_{\mathrm{k}}+\mathrm{x}_{\mathrm{jk}}+e_{\mathrm{ijk}}
$$

where: $y_{i j k}=A M I R$ of cow $i$ within the treatment group $\mathrm{k}$ at the time $\mathrm{j}$ of the measurements; $\mathrm{c}_{\mathrm{ik}}=\mathrm{cow}(\mathrm{i}=5)$ within the treatment group $\mathrm{k}$ as a random effect; $t_{j}=$ fixed effect of time $(j=0,14$ and 21 days $)$ of the measurements of AMIR; $f_{k}=$ fixed effect of the treatment group $(k=1-6) ; x_{j k}=$ fixed effect of time by treatment group and $e_{\mathrm{ijk}}=$ random or residual error term.

The model for DTH was as follows:

$$
\mathrm{y}_{\mathrm{ijklm}}=\mathrm{c}_{\mathrm{ik}}+\mathrm{t}_{\mathrm{j}}+\mathrm{f}_{\mathrm{k}}+\mathrm{s}_{1}+\mathrm{a}_{\mathrm{m}}+\mathrm{d}_{\mathrm{mlik}}+\mathrm{h}_{\mathrm{mk}}+\mathrm{g}_{\mathrm{mj}}+\mathrm{x}_{\mathrm{jk}}+\mathrm{z}_{\mathrm{mjk}}+e_{\mathrm{ijk}}
$$

where: $\mathrm{y}_{\mathrm{ijk} k \mathrm{~m}}=\mathrm{DTH}$ of cow $\mathrm{i}$ to antigen $\mathrm{m}$ by side 1 (left and right side of the neck) within treatment group $\mathrm{k}$ at the time $\mathrm{j}$ of the skin measurements; $\mathrm{c}_{\mathrm{ik}}=\mathrm{cow}(\mathrm{i}=5)$ within treatment group $\mathrm{k}$ as a random effect; $\mathrm{t}_{\mathrm{j}}=$ fixed effect of time $(j=0,6,24$ and $48 \mathrm{~h})$ of the measurements of DTH; $f_{k}=$ fixed effect of the treatment group $(\mathrm{k}=1-6) ; \mathrm{s}_{1}=$ fixed effect of side $(\mathrm{l}=$ left and right side of the neck); $\mathrm{a}_{\mathrm{m}}=$ fixed effect of the antigen ( $\mathrm{m}=$ PPD, phlein and PBS); $\mathrm{d}_{\mathrm{mlik}}=$ random effect of antigen $\mathrm{m}$ by side 1 (left and right side of the neck) by cow $\mathrm{i}$ within treatment group $\mathrm{k} ; \mathrm{h}_{\mathrm{mk}}=$ fixed effect of antigen by treatment group; $g_{m j}=$ fixed effect of antigen by time; $x_{j k}=$ fixed effect of time by treatment group; $\mathrm{z}_{\mathrm{mjk}}=$ fixed effect of antigen by time by treatment group and $e_{\mathrm{ijk}}=$ random or residual error term.

The LSM for time by treatment by antigen were used to construct contrasts using SAS ${ }^{\circledR}$ to obtain the increase of double skin-fold thickness from 0 to 6 , 24 or $48 \mathrm{~h}$ post-injections and to compare responses among treatment groups. Simple effects [20] Student t-tests, adjusted using Tukey HSD (honestly significant difference) approach [19], were used to decide if there were significant differences. The percent increase in double skin-fold thickness as an indicator of DTH was computed as previously described [8].

Pearson correlations (Statistix, Analytical Software, USA) were computed to examine the relationship between 21 day AMIR to OVA and DTH response to mycobacteria at 24 and $48 \mathrm{~h}$ for TG-II - TG-V. 


\section{RESULTS}

\subsection{Antibodies to OVA}

Primary (day 14) and secondary (day 21) serum antibody responses $(P \leq$ 0.05 ) were observed in all treatment groups (Fig. 2a). Antibody responses to OVA when given together with mycobacteria emulsified in a Freund adjuvant (TG-II, TG-III, and TG-IV) tended to be greater than when given in MCWE alone (TG-V and TG-VI).

\subsection{DTH to mycobacteria}

Percent increase of double skin-fold thickness as an indicator of DTH among treatment groups is shown in Figure 2b. Cows which received mycobacteria emulsified in a Freund adjuvant (TG-II, III, IV) had greater $(P \leq 0.05)$ DTH responses than the negative control. Cows that received MCWE emulsified in NUFA (TG-IV) also had DTH greater $(P \leq 0.05)$ than the positive control at $24 \mathrm{~h}$. Cows that received BCG and MCWE/phlein without an oil adjuvant (TG-V) had relatively little DTH response but it was significantly $(P \leq 0.05)$ greater than the negative control at $24 \mathrm{~h}$ post-injection. Cows within TG-VI (MCWE/phlein) showed no significant DTH response.

\subsection{Variation in antibodies to OVA and DTH to mycobacteria}

Classification of cows based on AMIR and DTH within each TG is illustrated in Table I. TG-1 (negative control) and TG-VI did not induce DTH and therefore cows receiving these treatments were not classified. Cows were ranked as $\mathrm{H}$, A or L responders based on primary and secondary serum AMIR on days 14 and 21, and DTH responses to mycobacteria observed at 24 and $48 \mathrm{~h}$. Most cows were within 1 standard deviation of the population mean and therefore were classified as average responders. Few cows were H or L for both AMIR and DTH or had opposing classification for these two traits. Changes in classification over time (14 versus 21 days for AMIR and 24 versus $48 \mathrm{~h}$ for DTH) occurred less frequently based on antibody ( $2 / 20$ cows) than DTH ( $6 / 20$ cows). Two cows within TG-I and TG-III had neither primary (day 14) nor secondary (day 21) antibody responses to OVA and therefore were classified as L antibody responders. There was no statistical correlation between AMIR and DTH responses at any time points, none the less it was still possible to find some cows which had generally high (e.g. cow 22) or low (e.g. cow 8) immune responses.

\subsection{Microarray analyses}

Microarray scans showed that mRNA from cows expressing $\mathrm{H}$ or $\mathrm{L}$ immune response phenotypes, and having significantly $(P \leq 0.05)$ different lymphocyte 
High and low immune responsiveness in cattle

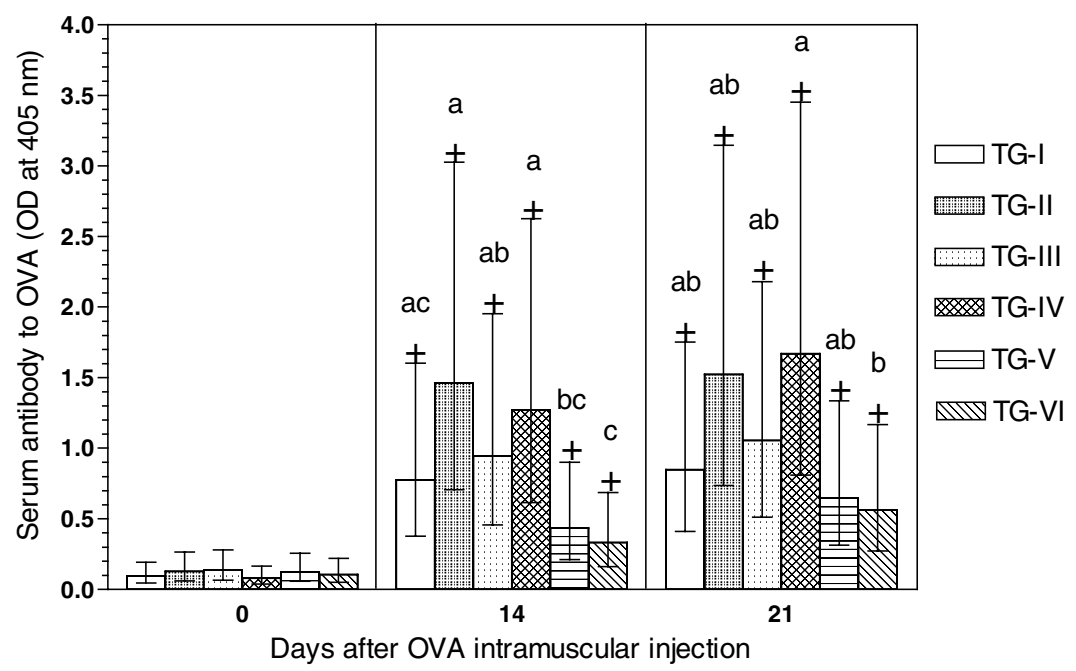

(a)

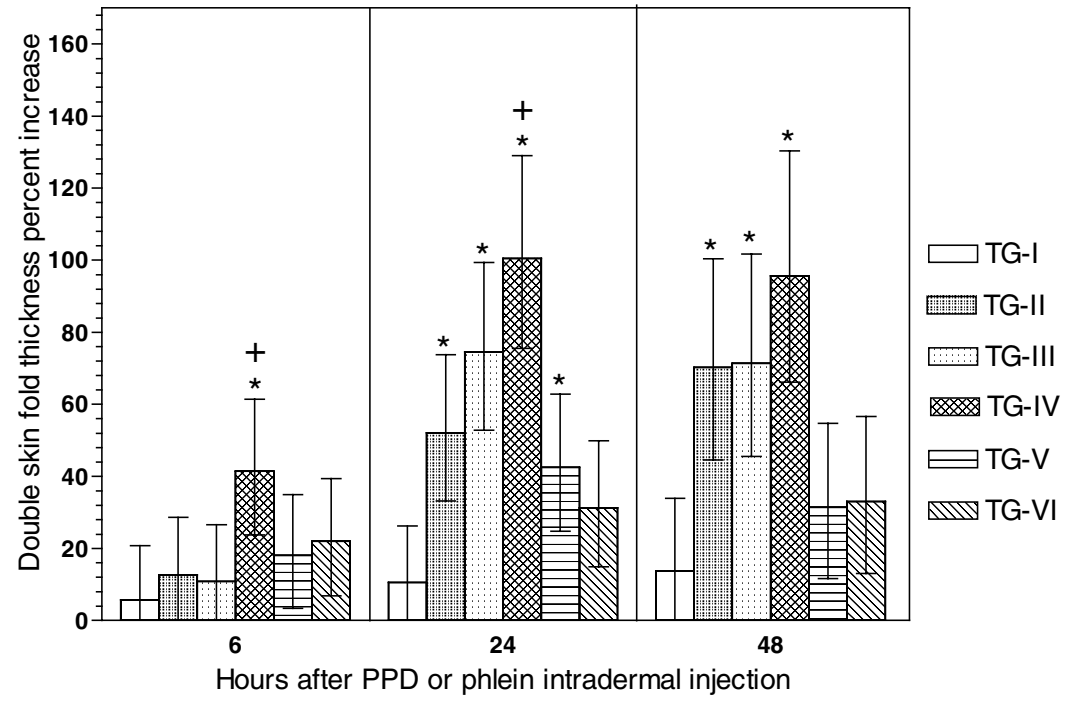

(b)

Figure 2. (a) Comparison of serum antibody responses to ovalbumin (OVA) at 14 and 21 days following immunization. Bars indicate confidence intervals; + indicates greater $(P \leq 0.05)$ response than day 0 ; different letters indicate different $(P \leq 0.05)$ responses between treatment groups. (b) Comparison of delayed-type hypersensitivity (DTH) to mycobacteria (Bacillus Calmette Guérin (BCG), M. tuberculosis or M. phlei) tested with either M. bovis purified protein derivative (PPD) or M. phlei PPD (phlein). Bars indicate confidence intervals; $*$ indicates greater $(P \leq 0.05)$ response than the negative control (no mycobacteria and non- ulcerative Freund adjuvant); + indicates greater $(P \leq 0.05)$ response than the positive control (BCG and Freund complete adjuvant). 
Table I. Classification of cows based on antibody to ovalbumin (days 14 and 21) and increase in double skin-fold thickness [delayed-type hypersensitivity (DTH) 24 and $48 \mathrm{~h}$ post-injection with $M$. bovis purified protein derivative (PPD) or M. phlei PPD (phlein)].

\begin{tabular}{lccccc}
\hline Treatment group & Cow \# & AMIR Day 14 & AMIR Day 21 & DTH 24 h & DTH 48 h \\
\hline II & 6 & H & H & A & A \\
& 7 & A & A & A & A \\
& 8 & L & L & L & A \\
& 9 & A & A & H & A \\
& 10 & A & A & A & H \\
\hline III & 11 & A & A & A & A \\
& 12 & A & A & A & A \\
& 13 & A & A & A & A \\
& 14 & A & A & A & A \\
& 15 & L & L & H & H \\
\hline IV & 16 & A & A & H & H \\
& 17 & A & A & A & A \\
& 18 & A & H & A & A \\
& 19 & A & A & A & A \\
\hline V & 20 & L & L & A & A \\
& 21 & A & A & A & A \\
& 22 & H & H & H & A \\
& 23 & A & A & A & L \\
& 24 & A & L & A & A \\
& 25 & A & A & A & H \\
\hline
\end{tabular}

High $(\mathrm{H})$, low (L), and average (A) responses were based on comparisons to the population mean \pm 1 standard deviation within treatment groups. TG-I (negative control) and TG-VI did not induce DTH and therefore, the cows in these treatments were not classified.

blastogenic responses to OVA and Con-A (data not shown) immediately prior to collection of mRNA, will hybridize to a standardized commercially available human array (Fig. 3). Therefore this approach could be utilized to identify genes, which differ between these cows. Although only two cows (one with the highest and one with the lowest immune response phenotype, cow numbers 22 and 8 , respectively) were used to test this procedure, image analysis showed that following lymphocyte stimulation with OVA, expression of 120 genes differed between $\mathrm{H}$ and $\mathrm{L}$ (refer to Tab. II for a selected sample of these genes). For example, CD14, high affinity immunoglobulin epsilon receptor gammasubunit precursor (FCEG), and MAP kinase-activativated protein kinase 2 

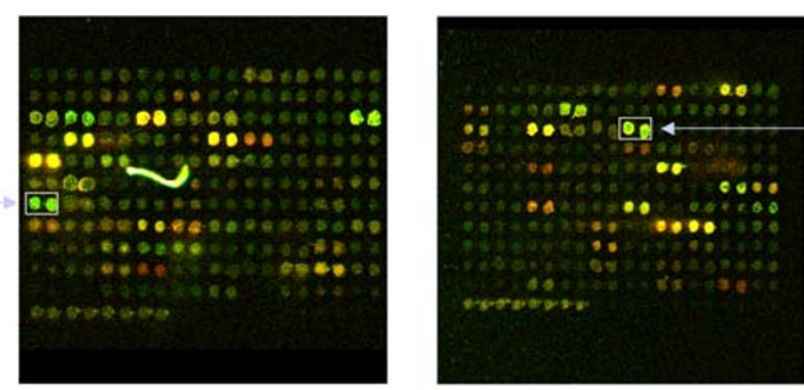

Zn finger binding

protein
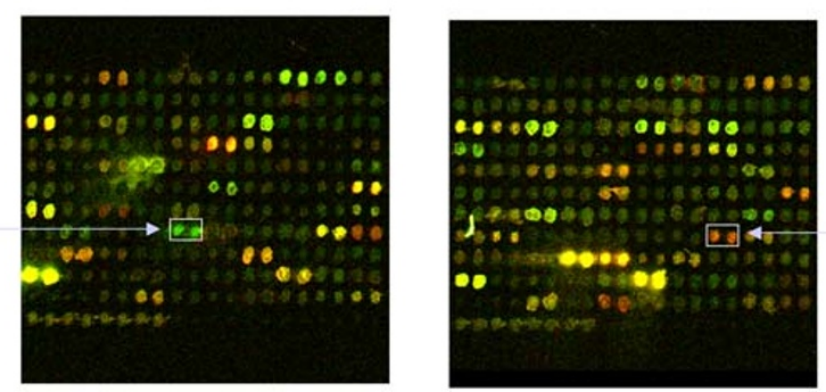

CD53

Figure 3. Different gene expression in 4 of 14 blocks of a $1.7 \mathrm{~K}$ human microarray following hybridization of RNA from cows $(n=2)$ classified as high or low immune responders. (This figure is available in color at www.edpsciences.org/gse).

(MKK2) gene spots had $\mathrm{Cy} 5 / \mathrm{Cy} 3$ ratios greater than 2.0 (strong red signal from the H-responder cow); whereas, interleukin (IL)-1B, IL-11, natural killer cell protein 4 precursor (NK4), and proteasome component C3 (PRC3) genes had ratios less than 0.5 (strong green signal from the L-responder cow). Following Con-A stimulation of lymphocytes from $\mathrm{H}$ and $\mathrm{L}$ cows, and hybridization of mRNA to the array, only 51 genes showed $\mathrm{Cy} 5 / \mathrm{Cy} 3$ ratios greater than 2.0 or less than 0.5 . There was little overlap in the genes showing differential expression following these two stimuli. At this point, these data can not infer that these genes are markers for $\mathrm{H}$ and $\mathrm{L}$ immune responsiveness, but only that this procedure can now be used to screen larger groups of cows classified as $\mathrm{H}$ or $\mathrm{L}$ to obtain information on the genes which underpin these discrete phenotypes.

\section{DISCUSSION}

Identification of livestock with enhanced AMIR and CMIR has been proposed as a means to improve broad-based resistance to infectious disease. In fact, Yorkshire pigs selected simultaneously for AMIR and DTH demonstrated health and production benefits $[10,23]$. Studies of Holsteins showed that cows 
Table II. Selected sample of genes from a $1.7 \mathrm{~K}$ human array with Cy5/Cy3 ratios greater than 2.0 or less than 0.5 following hybridization of RNA after in vitro stimulation of lymphocytes from two cows classified as high (red Cy5 labelled) or low (green Cy3 labelled) immune responders with ovalbumin or concanavalin A.

(continued on the next page)

\begin{tabular}{|c|c|c|c|c|}
\hline Abbreviations & Gene name & $\begin{array}{l}\text { Gene bank } \\
\text { accession } \\
\text { number }\end{array}$ & $\begin{array}{l}\text { OVA }^{\mathrm{a}} \\
\text { Ratio of } \\
\text { medians }\end{array}$ & $\begin{array}{l}\text { ConA }^{b} \\
\text { Ratio of } \\
\text { medians }\end{array}$ \\
\hline A2MG & Alpha-2-macroglobulin precursor & W24394 & $\begin{array}{l}0.336 \\
0.299\end{array}$ & $\begin{array}{l}2.133 \\
2.367\end{array}$ \\
\hline AHNK & $\begin{array}{l}\text { Neuroblast differentiation associated } \\
\text { protein ahnak }\end{array}$ & AA044249 & $\begin{array}{l}0.272 \\
0.241\end{array}$ & $\begin{array}{l}2.208 \\
2.615\end{array}$ \\
\hline ANPA & $\begin{array}{l}\text { Atrial natriuretic peptide receptor A } \\
\text { precursor }\end{array}$ & R47859 & $\begin{array}{l}0.183 \\
0.182\end{array}$ & $\begin{array}{l}-{ }^{c} \\
-\end{array}$ \\
\hline CD14 & LPS receptor & U00699 & $\begin{array}{l}4.404 \\
3.6\end{array}$ & - \\
\hline CD53 & $\begin{array}{l}\text { Leukocyte signal transducer MRC } \\
\text { OX44 }\end{array}$ & AW768547 & $\begin{array}{l}3.684 \\
3.564\end{array}$ & - \\
\hline CD63 & $\begin{array}{l}\text { Granulophysin lysosomal-membrane } \\
\text {-associated glycoprotein } 3\end{array}$ & BQ787167 & $\begin{array}{l}3.355 \\
3.307\end{array}$ & - \\
\hline CD68 & Melanoma-associated antigen (ME491) & BQ549982 & $\begin{array}{l}3.058 \\
2.969\end{array}$ & - \\
\hline CD82 & Leukocyte transducer 4F9 & BI445391 & $\begin{array}{l}2.316 \\
2.22\end{array}$ & - \\
\hline CLK1 & Protein kinase CLK1 & AA046192 & $\begin{array}{l}0.44 \\
0.421\end{array}$ & - \\
\hline CN1B & $\begin{array}{l}\text { Calcium/calmodulin-dependent } \\
3^{\prime}, 5^{\prime} \text {-cyclic nucleotide } \\
\text { phosphodiesterase } 1 \mathrm{~B}\end{array}$ & $\mathrm{R} 24757$ & $\begin{array}{l}0.421 \\
0.339\end{array}$ & - \\
\hline COF1 & Cofilin, non-muscle isoform & N39691 & $\begin{array}{l}3.332 \\
3.038\end{array}$ & $\begin{array}{l}0.272 \\
0.348\end{array}$ \\
\hline COXJ & $\begin{array}{l}\text { Cytochrome C oxidase polypeptide } \\
\text { VIIA-liver precursor }\end{array}$ & W78997 & $\begin{array}{l}2.355 \\
2.298\end{array}$ & $\begin{array}{l}4.427 \\
5.568\end{array}$ \\
\hline DDX5 & Probable RNA-dependent helicase P68 & W05242 & $\begin{array}{l}0.436 \\
0.375\end{array}$ & $\begin{array}{l}0.343 \\
0.418\end{array}$ \\
\hline FCEG & $\begin{array}{l}\text { High affinity immunoglobulin epsilon } \\
\text { receptor gamma-subunit precursor }\end{array}$ & H71637 & $\begin{array}{l}5.034 \\
4.367\end{array}$ & $\begin{array}{ll}- \\
- \\
-\end{array}$ \\
\hline FRIH & Ferritin light chain & R81846 & $\begin{array}{l}5.284 \\
4.797\end{array}$ & - \\
\hline HB21 & $\begin{array}{l}\text { HLA class II histocompatibility } \\
\text { antigen, DQ(1) beta chain precursor }\end{array}$ & AA029822 & - & $\begin{array}{l}0.165 \\
0.169\end{array}$ \\
\hline IF4B & $\begin{array}{l}\text { Eukaryotic translation initiation } \\
\text { factor } 4 \mathrm{~B}\end{array}$ & W32355 & - & $\begin{array}{l}0.436 \\
0.478\end{array}$ \\
\hline IL11 & Interleukin 11 & BG056707 & $\begin{array}{l}0.245 \\
0.185\end{array}$ & $\begin{array}{ll}- \\
- \\
-\end{array}$ \\
\hline IL1B & Interleukin 1B & BI335905 & $\begin{array}{l}0.12 \\
0.11\end{array}$ & - \\
\hline MKK2 & MAP kinase-activated protein kinase 2 & W69515 & $\begin{array}{l}5.936 \\
5.39 \\
\end{array}$ & $\begin{array}{l}- \\
-\end{array}$ \\
\hline
\end{tabular}


Table II. Continued.

\begin{tabular}{|c|c|c|c|c|}
\hline Abbreviations & Gene name & $\begin{array}{l}\text { Gene bank } \\
\text { accession } \\
\text { number }\end{array}$ & $\begin{array}{l}\text { OVA }^{\mathrm{a}} \\
\text { Ratio of } \\
\text { medians }\end{array}$ & $\begin{array}{l}\text { ConA }^{\mathrm{b}} \\
\text { Ratio of } \\
\text { medians }\end{array}$ \\
\hline MSH3 & DNA mismatch repair protein MSH3 & N44579 & $\begin{array}{l}0.47 \\
0.498\end{array}$ & $\begin{array}{ll}- \\
-\end{array}$ \\
\hline NK4 & Natural killer cells protein 4 precursor & AA131999 & $\begin{array}{l}0.344 \\
0.355\end{array}$ & $\begin{array}{l}- \\
-\end{array}$ \\
\hline$\overline{\mathrm{OB}}$ & Leptin precursor & H39701 & $\begin{array}{l}0.297 \\
0.351\end{array}$ & $\begin{array}{l}6.352 \\
6.253\end{array}$ \\
\hline PGH1 & Prostaglandin G/H synthase 1 precursor & R96180 & $\begin{array}{l}4.436 \\
4.002\end{array}$ & $\begin{array}{ll}- \\
- \\
\end{array}$ \\
\hline PIMT & $\begin{array}{l}\text { Protein-L-isoaspartate(D-aspartate) } \\
\text { O-methyl transferase }\end{array}$ & H16888 & $\begin{array}{l}0.519 \\
0.468\end{array}$ & $\begin{array}{l}- \\
-\end{array}$ \\
\hline$\overline{\text { PPP5 }}$ & Serine/threonine protein phosphatase 5 & AA023029 & $\begin{array}{l}5.195 \\
4.473\end{array}$ & $\begin{array}{l}- \\
-\end{array}$ \\
\hline PRC3 & Proteasome component $\mathrm{C} 3$ & W52537 & $\begin{array}{l}0.411 \\
0.489 \\
\end{array}$ & $\begin{array}{ll}- \\
- \\
\end{array}$ \\
\hline PRTP & Lysosomal protective protein precursor & W49687 & $\begin{array}{ll}- \\
- \\
-\end{array}$ & $\begin{array}{l}4.465 \\
4.293\end{array}$ \\
\hline RHOG & $\begin{array}{l}\text { RHO-related GTP-binding protein } \\
\text { RHOG }\end{array}$ & N94183 & $\begin{array}{l}2.565 \\
2.592\end{array}$ & $\begin{array}{l}2.673 \\
2.466\end{array}$ \\
\hline$\overline{R L 13}$ & 60S ribosomal protein L13 & W52072 & $\begin{array}{l}2.071 \\
2.923 \\
\end{array}$ & $\begin{array}{l}0.186 \\
0.18 \\
\end{array}$ \\
\hline RL39 & 60S ribosomal protein L39 & N53295 & $\begin{array}{l}0.304 \\
0.308\end{array}$ & $\begin{array}{l}0.394 \\
0.33\end{array}$ \\
\hline$\overline{\mathrm{RS} 27}$ & 40S ribosomal protein $\mathrm{S} 27$ & W21209 & $\begin{array}{ll}- \\
- \\
-\end{array}$ & $\begin{array}{l}0.042 \\
0.047\end{array}$ \\
\hline$\overline{\text { SAP }}$ & Proactivator polypeptide precursor & W67766 & $\begin{array}{l}7.767 \\
6.929\end{array}$ & $\begin{array}{ll}- \\
-\end{array}$ \\
\hline SOX4 & Transcription factor SOX-4 & W25479 & $\begin{array}{ll}- \\
- \\
-\end{array}$ & $\begin{array}{l}0.246 \\
0.316\end{array}$ \\
\hline SPIB & Transcription factor SPI-B & W01642 & $\begin{array}{l}0.346 \\
0.475\end{array}$ & $\begin{array}{l}0.476 \\
0.476\end{array}$ \\
\hline STCH & $\begin{array}{l}\text { Microsomal stress } 70 \text { protein ATPase } \\
\text { core precursor }\end{array}$ & R13040 & $\begin{array}{l}0.178 \\
0.15\end{array}$ & $\begin{array}{ll}- \\
- \\
\end{array}$ \\
\hline TDX2 & Thioredoxin peroxidase 2 & W92854 & $\begin{array}{l}- \\
-\end{array}$ & $\begin{array}{l}6.007 \\
5.411\end{array}$ \\
\hline TGFB & $\begin{array}{l}\text { Latent transforming growth factor beta } \\
\text { binding protein } 1 \text { precursor }\end{array}$ & AA044783 & $\begin{array}{l}0.433 \\
0.462\end{array}$ & $\begin{array}{ll}- \\
- \\
\end{array}$ \\
\hline TPM4 & $\begin{array}{l}\text { Tropomyosin, fibroblast non-muscle } \\
\text { type }\end{array}$ & W25296 & $\begin{array}{l}4.506 \\
4.495\end{array}$ & $\begin{array}{l}- \\
-\end{array}$ \\
\hline TR12 & Thyroid receptor interacting protein 12 & AA195116 & $\begin{array}{l}4 \\
4.818\end{array}$ & $\begin{array}{l}- \\
-\end{array}$ \\
\hline TRAD & $\begin{array}{l}\text { Tumor necrosis factor receptor type } 1 \\
\text { associated protein }\end{array}$ & W32666 & $\begin{array}{ll}- \\
-\end{array}$ & $\begin{array}{l}2.618 \\
2.253\end{array}$ \\
\hline TSP1 & Thrombospondin 1 precursor & W47517 & $\begin{array}{l}- \\
-\end{array}$ & $\begin{array}{l}15.181 \\
14.8\end{array}$ \\
\hline
\end{tabular}

${ }^{a}$ Values in this column represent the ratio of $\mathrm{Cy} 5 / \mathrm{Cy} 3$ medians for each of two duplicate gene array spots following hybridization with mRNA from cells stimulated with OVA. ${ }^{b}$ Values in this column represent ratio of $\mathrm{Cy} 5 / \mathrm{Cy} 3$ medians for each of two duplicate gene array spots following hybridization with mRNA from cells stimulated with ConA. ${ }^{c}(-)$ represents genes not expressed in the specified range. 
with high AMIR during the peripartum period had increased response to a commercial J5 E. coli vaccine and reduced mastitis in two out of three herds tested [21]. Therefore, the primary objective here was to find antigen-adjuvant combinations that induced both AMIR and CMIR, and which allowed cows to be categorized as $\mathrm{H}$ or $\mathrm{L}$. The secondary objective, having identified cows with $\mathrm{H}$ and $\mathrm{L}$ immune response phenotypes, was to determine if a commercially available human EST microarray could be used to detect possible genetic differences between these phenotypes and to establish methods to utilize this approach.

Primary (day 14) and secondary (day 21) antibody responses were observed in each treatment group, indicating that all immunization protocols induced antibody to OVA. A previous study of Holsteins during the peripartum period also used OVA given in conjunction with a $\mathrm{J} 5 \mathrm{E}$. coli vaccine to identify cows with $\mathrm{H}$ or L AMIR [21]. Indeed, a variety of protocols have been successfully used to effectively measure AMIR to OVA and classify cows (peripartum and dry) $[9,21]$.

In the current study, cows receiving mycobacteria emulsified in a Freund adjuvant developed DTH, which varied substantially between individuals and peaked 24 to $48 \mathrm{~h}$ post-injection of PPD or phlein. This DTH response is similar in time course to that described in other experiments [3,5]. Microscopically, most of the significant changes within treatment groups were observed in inflammation, as well as macrophage and lymphocyte infiltration, and appeared at $48 \mathrm{~h}$ post-injection.

The use of percent increase in double skin-fold thickness as a simple and reliable indicator of DTH and as a means to identify $\mathrm{H}$ and $\mathrm{L}$ responders is supported here in that DTH responses varied among cows within each treatment (11.13-224.77\% increase). Previous studies of pigs have also used a similar method to select individuals with $\mathrm{H}$ and L DTH for selective breeding [8]. Cows within all treatments, except for the negative control (TG-1), and those receiving OVA with MCWE alone (TG-VI), could be classified as $\mathrm{H}, \mathrm{L}$ or A for both AMIR and CMIR. Although this and a previous study [8] show no positive correlation between AMIR and CMIR it is still possible to identify some animals, which are $\mathrm{H}$ or L for both traits. Most cows had the highest AMIR to OVA at day 21 regardless of the treatment group, and the classification as $\mathrm{H}$ or $\mathrm{L}$ was similar at days 14 and 21 . However, classification based on DTH may vary between 24 and 48. Since differences in DTH responses over time can affect cow classification, it may be better to average 24 and $48 \mathrm{~h}$ responses or to monitor response curve kinetics and chose the time that has maximum genetic variation. Alternatively, DTH to multiple antigens could be assessed, as is the case with DTH testing of humans $[3,15]$. Although AMIR classification varied little between primary and secondary responses, ranking should be based on secondary responses in order to capture the ability 
to produce anamnestic responses. The lymphocyte proliferation assays using Con-A and OVA performed prior to microarray gene evaluation of the highest and lowest IR phenotypes (AMIR and DTH) confirmed the H or L status.

Microarrays were first used in 1995 to analyze differential gene expression in Arabidopsis [18] and have since been effectively used to study gene expression in a variety of species [1,2]. Although there are now at least two bovine arrays available $[14,24]$ these contain relatively few immune response genes and were not available at the outset of this study. However, given the large degree of genetic homology among mammalian species it seemed reasonable to test whether bovine mRNA could hybridize to a commercially available human array as a means to discover genes associated with these diverse phenotypes. Microarray scans showed that mRNA from cows expressing H or L immune response phenotypes will hybridize to a human array, and that this approach could be utilized to identify genes that differ between these cows. Given that these are only preliminary experiments this result can not infer that these genes are markers for $\mathrm{H}$ and $\mathrm{L}$ immune responsiveness, but only that this procedure can now be used to screen larger groups of cows classified as $\mathrm{H}$ or $\mathrm{L}$ to obtain accurate information on genes which underpin these unique phenotypes.

\section{CONCLUSIONS}

A variety of phenotypic and genetic markers have been suggested to select for disease resistance [4]. However, given the tremendous capacity of pathogens to vary their virulence mechanisms and that the immune system largely governs response to infectious diseases, it may be better to attempt to enhance broadbased disease resistance via enhanced immune responsiveness, rather than to target specific diseases or pathogens. With this in mind, several studies have sought to identify individuals within populations with $\mathrm{H}$ or $\mathrm{L}$ immune responses. Studies of mice have shown that selection for $\mathrm{H}$ or $\mathrm{L}$ antibody to sheep red blood cells is inversely associated with CMIR, and that the $\mathrm{H}$ antibody is associated with control of extracellular pathogens, but not intracellular organisms [13]. Studies of chickens also selected for the $\mathrm{H}$ or L antibody have reported similar findings $[6,16]$. However, selection of pigs for both H AMIR and CMIR indicates health and production benefits [8]. A recent study of cows during the peripartum period also suggests benefits to individuals with $\mathrm{H}$ antibody responsiveness [22]. To refine and improve this index, a simple, safe, and effective means was sought to induce both AMIR and CMIR for classifying $\mathrm{H}$ and $\mathrm{L}$ responders. The results of this study indicate that AMIR to OVA and DTH to mycobacteria can be used to classify cows. Future studies will seek to further refine indicators of CMIR, determine associations with health traits, and use microarrays as a means to discover genes which characterise these phenotypes. 


\section{ACKNOWLEDGEMENTS}

This research was supported by grants to B.A. Mallard from the Natural Sciences and Engineering Research Council of Canada, the Ontario Ministry of Agriculture and Food, and the Dairy Federation of Canada. We also gratefully acknowledge Dr. Gerald Jansen and William M. Sears for statistical advice.

\section{REFERENCES}

[1] Carson J.A., Nettleton D., Reecy J.M., Differential gene expression in the rat soleus muscle during early work overload-induced hypertrophy, FASEB J. 16 (2002) 207-209.

[2] Cleary J.D., Rogers P.D., Chapman S.W., Differential transcription factor expression in human mononuclear cells in response to amphotericin B: identification with complementary DNA microarray technology, Pharmacotherapy 21 (2001) 1046-1054.

[3] Frazer I.H., Collins E.J., Fox J.S., Jones B., Oliphant R.C., Mackay I.R., Assessment of delayed-type hypersensitivity in man: a comparison of the "Multitest" and conventional intradermal injection of six antigens, Clin. Immunol. Immunopathol. 35 (1985) 182-190.

[4] Kelley K.W., Greenfield R.E., Evermann J.F., Parish S.M., Perryman L.E., Delayed-type hypersensitivity, contact sensitivity, and phytohemagglutinin skintest responses of heat- and cold-stressed calves, Am. J. Vet. Res. 43 (1982) 775-779.

[5] Leslie K.E., Genetic selection for resistance to mastitis, 3rd International Mastitis Seminar Proceedings, 28 May to 1 June 1995, Tel Aviv, Israel, pp. 3-11.

[6] Lofthouse S.A., Andrews A.E., Nash A.D., Bowles V.M., Humoral and cellular responses induced by intradermally administered cytokine and conventional adjuvants, Vaccine 13 (1995) 1131-1137.

[7] Mallard B.A., Leslie K., Genetic regulation of immune response and mastitis resistance during the peripartum period of dairy cows, Proceedings of the 2nd International Symposium on Mastitis and Milk Quality, 13-15 September 2001, Vancouver, British Columbia, pp. 23-27.

[8] Mallard B.A., Wilkie B.N., Kennedy B.W., Genetic and other effects on antibody and cell mediated immune response in swine leukocyte antigen (SLA)-defined miniature pigs, Anim. Genet. 20 (1989) 167-178.

[9] Mallard B.A., Wilkie B.N., Kennedy B.W., Quinton M., Use of estimated breeding values in a selection index to breed Yorkshire pigs for high and low immune and innate resistance factors, Anim. Biotechnol. 3 (1992) 257-280.

[10] Mallard B.A., Sharif S., Sargeant J., Scott M., Dekkers J.C.M., Leslie K.E., Genetic selection for enhanced immune response and disease resistance in Canadian Holstein cattle, 3rd International Mastitis Seminar Proceedings, 28 May to 1 June 1995, Tel Aviv, Israel, pp. 13-20.

[11] Mallard B.A., Wilkie B.N., Kennedy B.W., Gibson J., Quinton M., Immune responsiveness in swine: eight generations of selection for high and low immune 
response in Yorkshire pigs, Proceedings of the 6th World Congress on Genetics Applied to Livestock Production, 11-16 January 1998, Vol. 27, University of New England, Armidale, pp. 257-262.

[12] Ontario Cancer Institute Web Page, Description of methods for use of distributed products: www.oci.utoronto.ca/services/microarray/products/.

[13] Puel A., Mevel J.-C., Bouthillier Y., Feingold N., Fridman W.H., Toward genetic dissection of high and low antibody responsiveness in Biozzi mice, Proc. Natl. Acad. Sci. USA 93 (1996) 14742-14746.

[14] Rebeiz M., Lewin H.A., Compass of 47787 Cattle ESTs, Anim. Biotechnol. 11 (2000) 75-241.

[15] Rogers A.S., Ellenberg J.H., Douglas S.D., Henry-Reid L., Peralta L., Wilson C.M., Performance of antigens used in detecting delayed-type hypersensitivity in adolescents infected with human immunodeficiency virus, Clin. Diagn. Lab. Immunol. 8 (2001) 273-278.

[16] Sarker N., Tsudzuki M., Nishibori M., Yasue H., Yamamoto Y., Cell-mediated and humoral immunity and phagocytic ability in chicken lines divergently selected for serum immunoglobulin M and G levels, Poult. Sci. 79 (2000) 1705-1709.

[17] SAS ${ }^{\circledR}$ Institute Inc., SAS ${ }^{\circledR} /$ STAT User's Guide, Version 8, Cary, NC, 1999.

[18] Shena M., Shalon D., Davis R.W., Brown P.O., Quantitative monitoring of gene expression patterns with a complementary DNA microarray, Science 270 (1995) 467-470.

[19] Sokal R.R., Rohlf F., J. Biometry, 3rd edn., W.H. Freeman and Co., NY, 1995.

[20] Steel R.G.D., Torrie J.H., Principles and procedures of statistics: a biometrical approach, 2nd edn., McGraw-Hill, Inc., 1980.

[21] Wagter L.C., Mallard B.A., Wilkie B.N., Leslie K.E., Boettcher P.J., Dekkers J.C.M., A quantitative approach to classifying Holstein cows based on antibody responsiveness and its relationship to peripartum mastitis occurrence, J. Dairy Sci. 83 (2000) 488-498.

[22] Wagter L.C., Mallard B.A., Wilkie B.N., Leslie K.E., Boettcher P.J., Dekkers J.C.M., The relationship between milk production and antibody response to ovalbumin during the peripartum period, J. Dairy Sci. 86 (2003) 169-173.

[23] Wilkie B.N., Mallard B.A., Selection for high immune response: an alternative approach to animal health maintenance, Vet. Immunol. Immunopathol. 72 (1999) 231-235.

[24] Yao J., Burton J.L., Saama P., Sipkovsky S., Coussens P.M., Generation of EST and cDNA Microarray resources for the study of bovine immunobiology, Acta Vet. Scand. 42 (2001) 391-405. 